\title{
Effect of Acetylation, Hydroxypropylation and Dual Acetylation-Hydroxypropylation on Physicochemical and Digestive Properties of Rice Starches with Different Amylose Content
}

\author{
Shah Asma Iftikhar ${ }^{1}$, Sayantan Chakraborty ${ }^{2}$ (D) , Himjyoti Dutta ${ }^{2, *(D)}$ \\ 1 Amity Institute of Food Technology, Amity University Uttar Pradesh, Sector 125, Noida, 201301, India; \\ asmaiftikhar619@gmail.com (S.A.I.); \\ 2 Department of Food Technology, Mizoram University, Aizawl, Mizoram, 796004, India; duttahimjyoti@gmail.com (H.D.); \\ * Correspondence: duttahimjyoti@gmail.com (H.D.);
}

Scopus Author ID 38561243800

Received: 22.09.2021; Revised: 20.10.2021; Accepted: 24.10.2021; Published: 20.11.2021

\begin{abstract}
Four rice (Oryza sativa L.) starches widely differing in amylose content were subjected to acetylation, hydroxypropylation, and dual modification involving acetylation followed by hydroxypropylation. The starches showed a higher affinity to hydroxypropyl substitution. However, acetylation caused a significant alteration in the glycosidic matrices. The changes in physicochemical properties were most prominent in the dual-modified samples. Hydroxypropylated and dual-modified granules showed greater swelling power with structural retention. Degrees of acetylation were high in the amorphous regions of waxy and low amylose starches (0.04 and 0.05). Minor granular swelling was observed under SEM. Substitution partially dissociated side-chain superhelices, lowering crystallinity values by $3.12-4.58 \%$, however retaining the native A-type XRD patterns. Glycosidic dissociation and enhanced hydrophilicity caused a significant lowering of gelatinization temperature (To, Tp, Tc), enthalpy $(\Delta \mathrm{H})$, and cooking time as observed from DSC and RVA results. Low setback viscosity and low syneresis during freeze-thaw cycles indicated the decreased tendency of modified starch chains to realign. Dual modified starches could be cooked to thinner and more precise pastes, which are highly resilient to retrogradation. Significant increases in enzyme-resistant RS and SDS (up to 20\% of each) were recorded. The dual modification method could suitably alter the properties of starches for food use.
\end{abstract}

Keywords: food grade; starch; hydroxypropylation; acetylation; dual modification.

(C) 2021 by the authors. This article is an open-access article distributed under the terms and conditions of the Creative Commons Attribution (CC BY) license (https://creativecommons.org/licenses/by/4.0/).

\section{Introduction}

Starch is the primary source of carbohydrates and energy in the human diet. Starch is composed of amylose and amylopectin. The linear amylose fraction comprises D-glucose monomers linked by $\alpha-1,4$-glycosidic linkages. Amylopectin is branched due to $\alpha-1,6$ branch points amongst the linear chains. Superhelices formed by amylopectin side chains contribute to starch crystallinity, amylose forms its major amorphous portions [1,2]. Starch has been used as an ingredient in processed foods for properties like swelling, gelatinization, solubility, and retrogradation. Native starches often do not accomplish all functional requirements because of https://biointerfaceresearch.com/ 
deficiencies such as high syneresis, rapid retrogradation, disintegration, and instability under shear stress [3]. Starch modifications are carried out to overcome undesirable characteristics and improve their physicochemical properties [4-6]. Physical, chemical, enzymatic, and genetic techniques of starch modification are available. Dual modification comprising two modification treatments on starch for exerting enhanced and multiple properties is a newer concept. Research on dual physical modification of rice and other starches had been reported [7-11]. Chemical modification generally results in altered intra- and intermolecular bonding, resulting in changed physicochemical and functional properties of starches. Chemical techniques encompassing oxidation, esterification, and etherification involve bonding association of reactive sites of hydroxyl groups of starch with new chemical groups, altering the chemical nature of the starch matrix. Acetylation involves the esterification of hydroxyl groups of the anhydrous glucose units of starch by acetyl ( $\left.\mathrm{CH}_{3} \mathrm{COO}-\right)$ groups (Figure 1). The substituted acetyl groups interrupt the ordered regions of starch and affect gelatinization and retrogradation, altering properties like swelling power, solubility, and stability of formed gel to temperature fluctuation. Reports are available on the acetylation of starches from different botanical sources [12]. Acetylated starches have been used in fruit pies, gravies, salad dressings, filled cakes, and biodegradable films. Changes in physicochemical properties of starch after acetylation depend on a number of factors, including source, granule size, amylose content, glycosidic chain length and arrangement, acetylation reagent, concentration, and $\mathrm{pH}[13,14]$.

Hydroxypropylation of starch involves etherification with propylene oxide under alkaline conditions (Figure 1). At higher $\mathrm{pH}$, hydroxyl groups of starch get converted to alkoxide groups which further react with the epoxide ring of propylene oxide. Etherification results in a lowered tendency of gelatinized starch paste to retrogradation8. Low gel opacity, improved freeze-thaw stability, lower gelatinization temperature, lower dissociation enthalpy, higher cold water solubility are few hydroxypropylated starch characteristics $[15,16]$. Studies indicate that granule size variation is not a contributing factor to the extent of hydroxypropylation [16]. Potato starch amylose got more hydroxypropylated than amylopectin under the same reaction conditions related to the non-alteration of amylopectin crystallite sizes after modification [17, 18]. A direct correlation of amylose content with the degree of etherification was reported by Kaur et al. (2004) [19]. However, the branch point regions of amylopectin could still show higher substitution [20]. Waxy amaranth starch gave higher substitution than normal maize starch [21]. Such irregularity also suggests that hydroxypropyl etherification within the starch matrix could be random. Maximum levels of acetyl and hydroxypropyl substitution in starch for food use have been recommended by the Food and Drug Administration (FDA).

Rice (Oryza Sativa L.) is a major food grain rich in starch. On the basis of apparent amylose content, Juliano (1979) classified rice varieties into high amylose $(>25 \%)$, intermediate amylose (20-25\%), low amylose (7-20\%) and waxy (0-2\%) [22]. Due to this primary difference in the macromolecular build-up, rice from these classes and starches extracted from them behave differently to different processing and modification treatments. Bearing one of the smallest granule size and versatility in physicochemical properties, rice starch is an ideal model for experimentation on chemical modification. Acetylation and hydroxypropylation as individual modification techniques have been applied to rice and other starches [23-31]. 


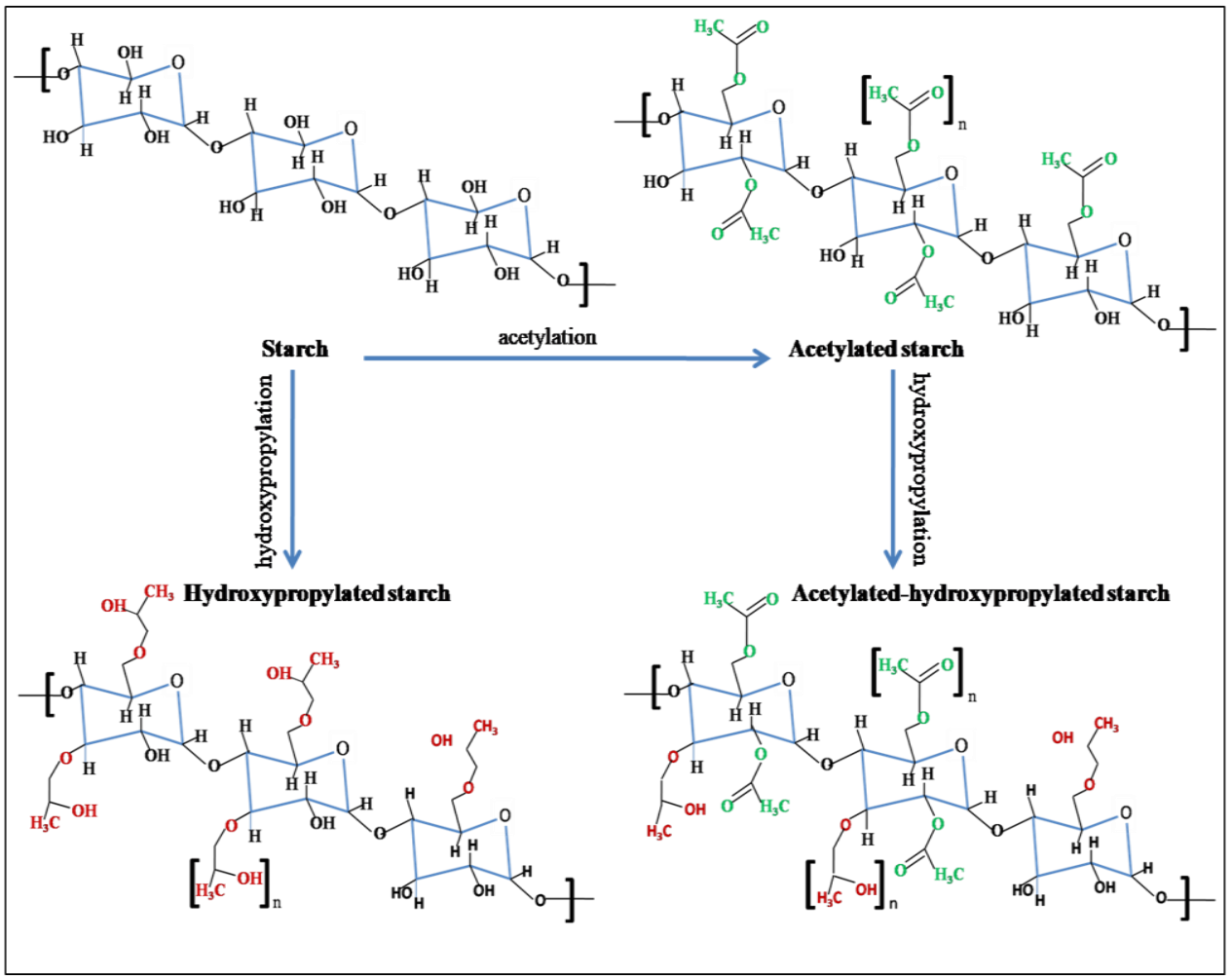

Figure 1. Schematic showing the chemical structures of single acetylation, hydroxypropylation, and dual acetylation-hydroxypropylation modified starches.

However, no study on the effect of the two chemical modifications on starches from the same plant origin but differing in amylose content, as in rice, could be found. This makes a combination of the two methods as a dual modification treatment for rice starches reasonable. In this study, starches extracted from one each of high amylose, intermediate amylose, low amylose, and waxy rice varieties were subjected to acetylation, hydroxypropylation, and dual modification. Changes in different chemical, physicochemical, and in vitro digestibility properties were analyzed.

\section{Materials and Methods}

Previously extracted starches from Ranjit (HR), Mushkbudij (IM), SRl (LS), and Aghoni bora (WA) rice variety samples collected from Agricultural Research Stations of Assam and Kashmir were used for the study [7]. Analytical grade chemicals and reagents were purchased from HiMedia, India.

\subsection{Apparent amylose content.}

Apparent amylose content (AAC, \% db) was estimated out using the method of Sowbhagya $\&$ Bhattacharya (1979) as specified for milled rice [32].

\subsection{Acetylation.}

Acetylation of starch was carried out as per the method of Granza et al. (2015) with modifications (Figure 2) [4]. Briefly, $200 \mathrm{~g}$ starch (db) was dispersed in $1000 \mathrm{ml}$ distilled water 
and $\mathrm{pH}$ adjusted at $10.0 \mathrm{using} 0.1 \mathrm{M} \mathrm{NaOH}$. Under constant agitation, $2 \mathrm{~g}$ vinyl acetate was added dropwise with simultaneous adjustment of $\mathrm{pH}$. After allowing the reaction for $5 \mathrm{~min}, 0.5 \mathrm{~N} \mathrm{HCl}$ was used to lower down $\mathrm{pH}$ to 4.5 , which terminated the reaction. The residue was collected, washed five times with double distilled water, and dried at $40^{\circ} \mathrm{C}$ for $48 \mathrm{~h}$. Acetylated samples were coded as HRA, IMA, LSA, and WAA.

\subsection{Hydroxypropylation.}

$100 \mathrm{~g} \mathrm{(db)} \mathrm{starch} \mathrm{was} \mathrm{added} \mathrm{to} \mathrm{a} 500 \mathrm{ml} 0.3 \%$ sodium sulfate solution (Figure 2). The slurry was stirred, $\mathrm{pH}$ adjusted to 9.5 with $0.1 \mathrm{M} \mathrm{NaOH}$, and $0.5 \mathrm{ml}$ of $0.5 \%$ (w/w) propylene oxide solution was added dropwise. After continuing at $40^{\circ} \mathrm{C}$ for $15 \mathrm{~min}$, the reaction was stopped by bringing down the $\mathrm{pH}$ to 5.5 using $0.5 \mathrm{~N} \mathrm{HCl}$. The residues for each sample were repeatedly washed, dried, and coded as HRH, IMH, LSH, and WAH [4].

\subsection{Dual modification.}

$100 \mathrm{~g}$ of each acetylated starch was hydroxypropylated as described above. These dualmodified samples were coded as HRAH, IMAH, LSAH, and WAAH (Figure 2).

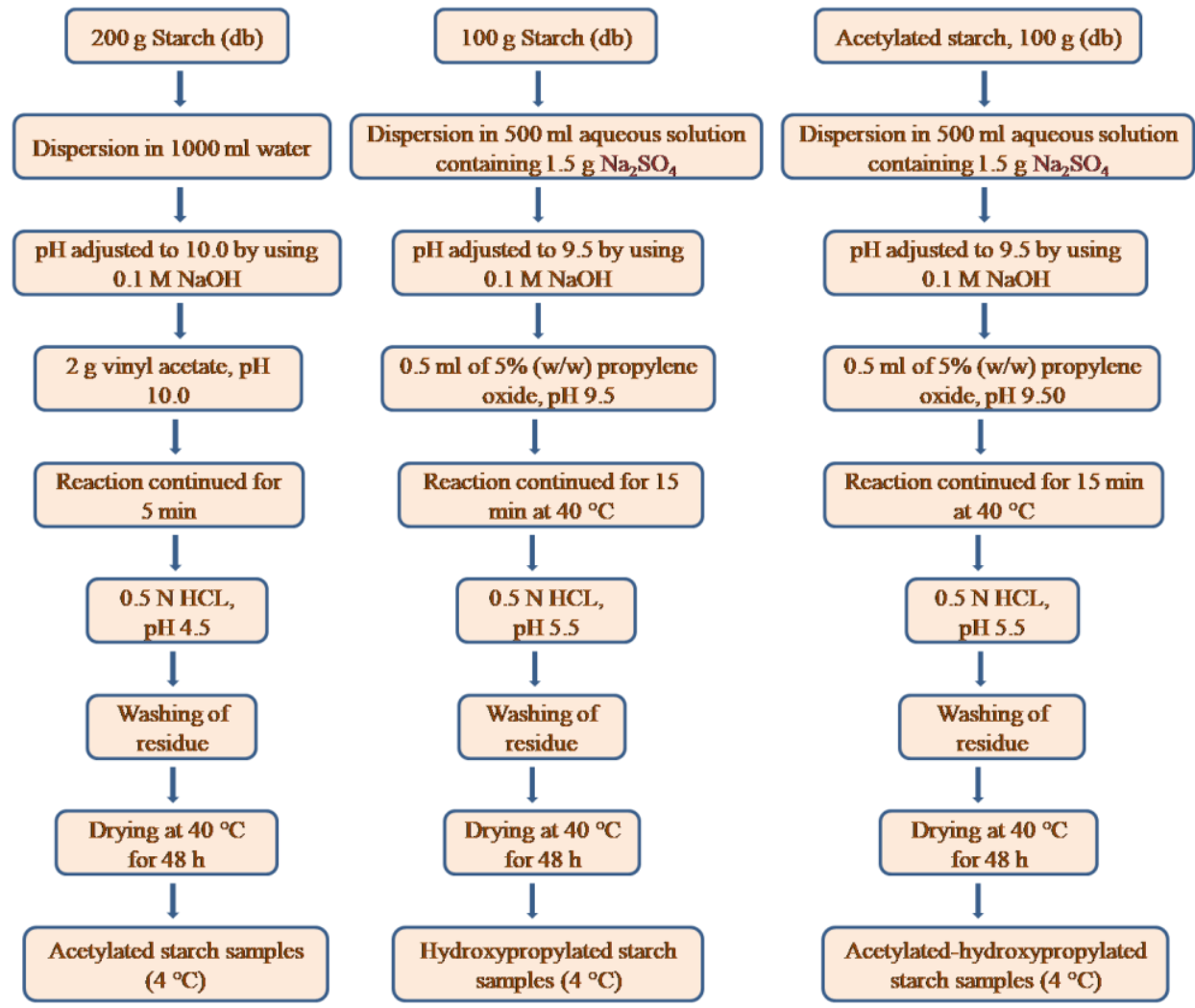

Figure 2. Flow diagram describing the reaction conditions used for producing acetylated, hydroxypropylated, and acetylated-hydroxypropylated starches.

\subsection{Acetyl group percentage and degree of substitution.}

$1 \mathrm{~g}$ acetylated starch was added to $50 \mathrm{ml} 75 \%$ ethanol in a stoppered flask and heated at $50^{\circ} \mathrm{C}$ for $30 \mathrm{~min}$, cooled to room temperature $\left(\mathrm{RT}=25 \pm 2^{\circ} \mathrm{C}\right), 40 \mathrm{ml}$ of $0.5 \mathrm{M} \mathrm{KOH}$ was added and stirred $(200 \mathrm{rpm})$ for $72 \mathrm{~h}$. The mixture was then titrated against $0.05 \mathrm{M} \mathrm{HCl} \mathrm{using} \mathrm{phenolphthalein}$ 
indicator. The titrated solution was allowed to stand for $2 \mathrm{~h}$, letting release of additional alkali and again titrated. Native starch was used as a reference. Acetyl group percentage (ACG \%) and degree of substitution (DS) were calculated [13].

$$
\begin{gathered}
A C G(\%)=\frac{(\text { Titre value of reference }- \text { Titre value of sample }) \times 0.05 \times 0.043 \times 100}{\text { Sample weight }} \\
D S=\frac{162 \times A C G}{4300-(42 \times A C G)}
\end{gathered}
$$

\subsection{Hydroxypropyl group percentage and degree of substitution.}

$0.1 \mathrm{~g}$ starch taken in the volumetric flask was mixed with $25 \mathrm{ml}_{1} \mathrm{~N} \mathrm{H}_{2} \mathrm{SO}_{4}$ and cooked in a water bath to obtain a clear solution. After cooling to RT, volume was made up to $100 \mathrm{ml}$ using distilled water. $1 \mathrm{ml}$ of this solution was taken in a chilled conical flask, and $8 \mathrm{ml}$ concentrated $\mathrm{H}_{2} \mathrm{SO}_{4}$ was added. The flask was then heated in a boiling water bath for 20 minutes and brought down to RT before shifting to an ice bath. Then, $0.6 \mathrm{ml}$ of $3 \%$ ninhydrin reagent made in $5 \%$ sodium metabisulphite was added, thoroughly mixed, and stored at RT for $1 \mathrm{~h}$. Volume was made up to $25 \mathrm{ml}$ with concentrated $\mathrm{H}_{2} \mathrm{SO}_{4}$ before reading absorbance at $590 \mathrm{~nm}$ in a UV Spectrophotometer (Motras Scientific, India), taking native starch as reference. The calibration curve was prepared from aliquots of standard aqueous solutions containing propylene glycol. Values of percentage hydroxypropyl groups (HPG \%) and DS were calculated [25].

$$
\begin{gathered}
H P G(\%)=\frac{\text { Amount of propylene glycol in } \mu \mathrm{g} / \mathrm{ml} \times 0.7763 \times 10}{\text { Weight of Sample }} \\
D S=\frac{162 \times H P G}{5800-58 \times H P G}
\end{gathered}
$$

\subsection{Swelling power and solubility.}

$1 \mathrm{~g}$ starch was dispersed in $20 \mathrm{ml}$ water in a pre-weighed centrifuge tube and heated in a shaking water bath at $50,60,70,80$, and $90^{\circ} \mathrm{C}$ for $30 \mathrm{~min}$. After cooling to RT, the suspension was centrifuged (3500 rpm, $15 \mathrm{~min}$ ). Swelling power (SP, g/g) was evaluated as the gain in weight of swollen sample per gram of dry mass. The supernatant was dried in pre-weighed Petri dish, and the ratio of dried supernatant weight to initial dry starch weight was calculated as solubility index (SI).

\subsection{Freeze-thaw stability.}

$30 \mathrm{ml}$ slurry containing $1.5 \mathrm{~g}$ starch in a glass centrifuge tube was cooked at $90^{\circ} \mathrm{C}$ for 10 min, cooled at RT for $30 \mathrm{~min}$, and excess water was carefully discarded. Then, the sample tube was kept at $-16^{\circ} \mathrm{C}$ for $24 \mathrm{~h}$, followed by thawing at RT for $6 \mathrm{~h}$ and weighing the released liquid. Seven cycles of freezing and thawing were done, and percent syneresis during each cycle was expressed as per the unit dry weight of the starch sample. 


\subsection{Light transmittance.}

$50 \mathrm{ml}$ of $1 \%$ starch slurry was prepared in a test tube and cooked for $10 \mathrm{~min}$ in a boiling water bath. The prepared paste was cooled and stored at $4{ }^{\circ} \mathrm{C}$. The transmittance of the retrograding paste was measured at $640 \mathrm{~nm}$ after $24 \mathrm{~h}$ intervals, taking distilled water as blank and expressed in percentage.

\subsection{Scanning electron microscopy.}

The native and modified starch samples' morphology was observed using a scanning electron microscope (SEM, EVO-18, Zeiss, Germany). Samples were vacuum dried, fixed on double-sided tape, sputter-coated with gold, and observed at 5000x magnification.

\subsection{X-ray diffraction.}

Starch samples were scanned in an X-ray diffractometer (XRD, MiniFlex 600, Rigaku, Japan) with $\lambda=1.54$, acceleration potential $=40 \mathrm{kV}$, current $=15 \mathrm{~mA}$, and fitted with a copper target. The diffraction curves were analyzed for change in pattern and crystallinity. Percentage crystallinity was calculated.

$$
\text { Crystallinity }(\%)=\frac{\text { Area under prominent peaks }}{\text { Total area under diffractogram }} \times 100
$$

\subsection{Differential scanning calorimetry.}

Thermal transitions of native and modified starches were determined in a differential scanning calorimeter (DSC, STARe System, Mettler-Toledo, Switzerland). $5 \mathrm{mg}$ (db) sample was weighed in a platinum pan. To this, $12 \mu \mathrm{l}$ deionized water was added, and the can was hermetically sealed. After keeping at RT for $12 \mathrm{~h}$ for moisture equilibration, the pan was heated from $20^{\circ} \mathrm{C}$ to $200^{\circ} \mathrm{C}$ at $10^{\circ} \mathrm{C} / \mathrm{min}$ rate under a nitrogen atmosphere. An empty pan was used as a reference. Thermal parameters, namely onset $\left(\mathrm{T}_{\mathrm{o}}\right)$, peak $\left(\mathrm{T}_{\mathrm{p}}\right)$, conclusion $\left(\mathrm{T}_{\mathrm{c}}\right)$ temperatures, and enthalpy of gelatinization $(\Delta \mathrm{H})$, were obtained from the inbuilt software.

\subsection{Pasting properties.}

A rapid viscosity analyzer (RVA, TechMaster, Perten Instruments, Australia) was used for evaluating the pasting properties of the starch samples. Prepared slurry ( $3 \mathrm{~g}$ dry starch in $25 \mathrm{ml}$ distilled water) was heated at $50^{\circ} \mathrm{C}$ for $1 \mathrm{~min}$, then raised the temperature to $95^{\circ} \mathrm{C}$ at a rate of $12.2^{\circ} \mathrm{C} / \mathrm{min}$. After holding at $95^{\circ} \mathrm{C}$ for $2.5 \mathrm{~min}$, the paste was cooled down to $50^{\circ} \mathrm{C}$ at the rate $11.8^{\circ} \mathrm{C} / \mathrm{min}$ and then again held for $2 \mathrm{~min}$. Pasting parameters, namely pasting temperature (PT, ${ }^{\circ} \mathrm{C}$ ), peak viscosity (PV, cP), hot paste viscosity ( $\mathrm{HPV}, \mathrm{cP}$ ), cold paste viscosity ( $\left.\mathrm{FV}, \mathrm{cP}\right)$, breakdown $(\mathrm{BD}, \mathrm{cP})$, and setback $(\mathrm{SB}, \mathrm{cP})$ were recorded.

\subsection{Infrared spectroscopy.}

The infrared spectra of native, single modified, and dual modified starches were obtained using a Fourier Transform Infrared (FTIR) spectrometer (Cary 630, Agilent Technologies, USA) 
operating at a resolution of $2.0 \mathrm{~cm}^{-1}$ with $\mathrm{KBr}$ optics within a wavenumber range of 650 to 4000 $\mathrm{cm}^{-1}$.

\subsection{Digestive properties.}

The extent and rate of starch digestion are indicated by its glucose liberation pattern. The method of Englyst et al. (1992) was used to quantify enzyme resistant starch (RS), slowly digestible starch (SDS), and rapidly digestible starch (RDS) fraction in the samples [33]. RDS and SDS were calculated from the values of glucose liberated at the $20^{\text {th }}$ and $120^{\text {th }}$ minute of incubation and expressed in a percentage ratio to that of total dry matter starch (TS). Undigested starch remaining after 120 min was considered as RS.

$$
\begin{gathered}
R D S(\%)=\frac{G_{20} \times 0.9}{T S} \times 100 \\
S D S(\%)=\frac{G_{120}-G_{20}}{T S} \times 100 \\
R S(\%)=[T S-(R D S+S D S)] \times 100
\end{gathered}
$$

The rates of in vitro enzymatic hydrolysis of the starch samples were measured by the method of Goni et al. (1996) [34]. Percentages of starch hydrolyzed during the hydrolytic incubation intervals of $20 \mathrm{~min}$ were calculated and expressed as the degree of hydrolysis (\%, db).

\subsection{Statistical analysis.}

Mean values of results for each parameter were compared for significance in the difference (level $=0.05$ ) using Duncan's multiple range test using SPSS 11.5 (SPSS Inc., USA) software.

\section{Results and Discussion}

\subsection{Apparent amylose content.}

The AAC of the native starch samples, namely HRN, IMN, LSN, and WAN was estimated to be $27.2 \%, 22.7 \%, 9.8 \%$, and $0.3 \%$, reconfirming them as high amylose, intermediate amylose, low amylose, and waxy varieties, respectively.

\subsection{Degrees of substitution and percentage of substituent groups.}

ACG of single modified HRA, IMA, LSA and WAA were below the maximum recommended value of $2.5 \%$ (FDA). DS followed the order LSA>WAA>IMA>HRA (Table 1). LSA and WAA showed a greater percentage of acetyl groups than HRA and IMA. Lee et al. (2015), from their study on japonica and indica rice starches, also opined that acetyl substitution favorably occurs in the amorphous regions of amylopectin than the generally amorphous amylose [24]. Therefore, lower DS and ACG of WAA than LSA could be due to a higher proportion of long amorphous chains between the crystalline portion in the latter. HPG and DS values of HRH, $\mathrm{IMH}, \mathrm{LSH}$, and WAH were also within the maximum range (7.0\% and 0.2, respectively) approved by FDA. LSH showed the highest DS, depicting that LSN was the most susceptible to both acetylation and hydroxypropylation. HRH and WAH showed lower DS for hydroxypropylation. 
Higher values of HPG than ACG depicted a higher affinity of the glycosidic reaction sites for hydroxypropylation. HPG was higher in dual-modified samples. DS slightly enhanced for HRAH and WAAH, declined for LSH, and remained the same for IMH, which could be due to differences in the structural organization of starch chains for entanglement of the acetyl and hydroxypropyl moieties.

Table 1. Apparent amylose content of native samples, percentage of substituted groups in the modified samples, degrees of substitution, crystallinity percentages, and thermal parameter values of native and modified starch samples.

\begin{tabular}{|c|c|c|c|c|c|c|c|c|}
\hline & \multirow{2}{*}{$\begin{array}{c}\mathbf{A A C} \\
(\%)\end{array}$} & \multirow{2}{*}{$\begin{array}{l}\text { Substituent } \\
\text { groups }(\%)\end{array}$} & \multirow{2}{*}{ DS } & \multirow{2}{*}{$\begin{array}{c}\text { Crystallinity } \\
(\%)\end{array}$} & \multicolumn{4}{|c|}{ DSC parameters } \\
\hline & & & & & To & $\mathrm{Tp}$ & Tc & $\Delta \mathbf{H}$ \\
\hline HRN & $27.2 \pm 0.9 \mathrm{~d}$ & - & - & $8.79 \pm 0.02 b c$ & $51.28 \pm 0.56 \mathrm{e}$ & $70.12 \pm 0.821$ & $93.11 \pm 0.89 n$ & $9.23 \pm 0.03 \mathrm{~cd}$ \\
\hline HRA & - & $1.37 \pm 0.00 \mathrm{a}$ & $0.02 \pm 0.005 \mathrm{e}$ & $6.80 \pm 0.08 \mathrm{~g}$ & $50.82 \pm 0.23 \mathrm{e}$ & $67.71 \pm 0.21 b$ & $91.32 \pm 0.34 d$ & $6.84 \pm 0.05 \mathrm{ef}$ \\
\hline $\mathrm{HRH}$ & - & $5.66 \pm 0.01 \mathrm{ab}$ & $0.16 \pm 0.003 b c$ & $7.43 \pm 0.09 \mathrm{~g}$ & $45.77 \pm 0.37 b$ & $68.56 \pm 0.43 \mathrm{f}$ & $89.62 \pm 0.43 \mathrm{e}$ & $8.71 \pm 0.00 \mathrm{a}$ \\
\hline HRAH & - & $5.82 \pm 0.01 \mathrm{ab}$ & $0.17 \pm 0.004 \mathrm{~cd}$ & $5.67 \pm 0.00 \mathrm{a}$ & $42.53 \pm 0.29 \mathrm{a}$ & $67.31 \pm 0.73 \mathrm{k}$ & $91.49 \pm 0.55 \mathrm{~g}$ & $8.4 \pm 0.02 b c$ \\
\hline IMN & $22.7 \pm 0.7 \mathrm{c}$ & - & - & $9.81 \pm 0.01 \mathrm{ab}$ & $61.28 \pm 0.45 \mathrm{~g}$ & $67.72 \pm 0.23 c$ & $78.56 \pm 0.24 \mathrm{c}$ & $8.79 \pm 0.04 \mathrm{de}$ \\
\hline IMA & - & $1.75 \pm 0.00 \mathrm{a}$ & $0.03 \pm 0.002 \mathrm{ab}$ & $7.63 \pm 0.02 b c$ & $57.87 \pm 0.35 \mathrm{f}$ & $65.31 \pm 0.57 \mathrm{i}$ & $94.02 \pm 0.9 \mathrm{o}$ & $6.71 \pm 0.03 \mathrm{~cd}$ \\
\hline $\mathrm{IMH}$ & - & $5.74 \pm 0.03 c$ & $0.17 \pm 0.004 \mathrm{~cd}$ & $8.47 \pm 0.01 \mathrm{ab}$ & $58.72 \pm 0.32 \mathrm{f}$ & $66.16 \pm 0.90 \mathrm{~m}$ & $94.81 \pm 0.12 \mathrm{a}$ & $8.23 \pm 0.01 \mathrm{ab}$ \\
\hline IMAH & - & $5.89 \pm 0.02 b c$ & $0.17 \pm 0.004 \mathrm{~cd}$ & $5.23 \pm 0.00 \mathrm{a}$ & $57.41 \pm 0.34 \mathrm{f}$ & $66.83 \pm 0.13 \mathrm{a}$ & $99.22 \pm 0.65 \mathrm{i}$ & $7.11 \pm 0.05 \mathrm{ef}$ \\
\hline LSN & $9.8 \pm 0.5 b$ & - & - & $9.69 \pm 0.03 \mathrm{~cd}$ & $64.69 \pm 0.22 \mathrm{~h}$ & $69.72 \pm 0.27 \mathrm{~d}$ & $81.36 \pm 0.71 \mathrm{j}$ & $9.1 \pm 0.01 \mathrm{ab}$ \\
\hline LSA & - & $2.01 \pm 0.00 \mathrm{a}$ & $0.05 \pm 0.003 \mathrm{~cd}$ & $8.32 \pm 0.04 \mathrm{de}$ & $47.01 \pm 0.75 b c$ & $67.31 \pm 0.67 \mathrm{j}$ & $94.72 \pm 0.21 \mathrm{~b}$ & $7.49 \pm 0.07 \mathrm{~g}$ \\
\hline LSH & - & $5.82 \pm 0.02 b c$ & $0.18 \pm 0.001 \mathrm{a}$ & $8.69 \pm 0.05 \mathrm{ef}$ & $47.41 \pm 0.42 \mathrm{bc}$ & $68.46 \pm 0.45 \mathrm{~g}$ & $90.23 \pm 0.76 \mathrm{k}$ & $8.17 \pm 0.03 \mathrm{~cd}$ \\
\hline LSAH & - & $5.97 \pm 0.01 \mathrm{ab}$ & $0.17 \pm 0.003 b c$ & $6.15 \pm 0.01 \mathrm{ab}$ & $49.57 \pm 0.35 \mathrm{de}$ & $67.71 \pm 0.21 \mathrm{~b}$ & $93.27 \pm 0.811$ & $7.72 \pm 0.06 \mathrm{fg}$ \\
\hline WAN & $0.3 \pm 0.00 \mathrm{a}$ & - & - & $12.82 \pm 0.01 \mathrm{ab}$ & $61.12 \pm 0.78 \mathrm{~g}$ & $66.43 \pm 0.55 \mathrm{~h}$ & $82.6 \pm 0.42 \mathrm{e}$ & $12.1 \pm 0.09 \mathrm{~h}$ \\
\hline WAA & - & $1.99 \pm 0.01 \mathrm{ab}$ & $0.04 \pm 0.02 \mathrm{ab}$ & $8.89 \pm 0.08 \mathrm{f}$ & $48.27 \pm 0.66 \mathrm{~cd}$ & $63.90 \pm 0.12 \mathrm{a}$ & $91.4 \pm 0.59 \mathrm{~h}$ & $8.27 \pm 0.01 \mathrm{ab}$ \\
\hline WAH & - & $5.66 \pm 0.02 b c$ & $0.16 \pm 0.003 b c$ & $9.37 \pm 0.06 \mathrm{~g}$ & $42.53 \pm 0.41 \mathrm{a}$ & $65.60 \pm 0.39 \mathrm{e}$ & $91.34 \pm 0.48 \mathrm{f}$ & $11.31 \pm 0.00 \mathrm{a}$ \\
\hline WAAH & - & $5.74 \pm 0.02 b c$ & $0.17 \pm 0.004 \mathrm{~cd}$ & $8.71 \pm 0.02 b c$ & $47.65 \pm 0.34 c$ & $59.42 \pm 0.57 j$ & $96.13 \pm 0.87 \mathrm{~m}$ & $10.18 \pm 0.05 \mathrm{ef}$ \\
\hline
\end{tabular}

\subsection{Swelling power and solubility.}

SP values of HRN, IMN, LSN, and WAN samples ranged from 5.85 to $11.04,5.93$ to $11.17,5.01$ to 11.19 , and 7.14 to 14.88 with a stepwise rise in temperature from $50^{\circ} \mathrm{C}$ to $90^{\circ} \mathrm{C}$ (Figure 3a). The corresponding SI values ranged from 0.45 to $0.86,0.35$ to $0.79,0.14$ to 0.27 and 0.12 to 0.24 , respectively. Amylopectin primarily influences the swelling of cooked cereal starches, whereas amylose is the diluent and swelling inhibitor. The highest solubility of HRN (Figure 3b) was due to more soluble amylose in it [35]. Modified starch samples showed higher SP and SI than the native starches. Acetyl groups weakened the inter- and intra-molecular hydrogen bonds, causing disordering of molecular arrangements, facilitating increased water access to the amorphous domains and leaching, as were also reported by several authors in rice, potato, finger millet, and Indian horse chestnut starches [36-39]. The swelling power of acetylated starches was in inverse accordance with apparent amylose content. Hydrophilic hydroxypropyl groups also facilitated water uptake, accelerating granular swelling [40, 41]. Hydroxypropylated and dual-modified starches showed greater SP than acetylated starches.

\subsection{Freeze-thaw stability.}

The syneresis (\%) of starch pastes are shown in Figure 3 (c). Amylose content was directly proportional to the extent of syneresis. Native starches showed values ranging from 35-70\%, 22$66 \%, 20-57 \%, 11.3-45.1 \%$ for HRN, IMN, LSN, and WAN, respectively. All three modifications resulted in lowered crystallization tendencies of the pastes, indicated by lower syneresis values. 
Hydroxypropylated starches showed the lowest syneresis, followed by acetylatedhydroxypropylated and acetylated starches for all starches. Therefore, modification resulted in enhanced freeze-thaw stability.

\subsection{Light transmittance.}

Paste clarity enhanced after modifications (Fig. 3d). Transmittance values of acetylated, hydroxypropylated, and acetylated-hydroxypropylated starches were notably higher than the native starches. These substituted moieties hindered the chain association, lowering the turbidity of the pastes. Paste clarity values showed an inverse relation with crystallinity percentages $(\mathrm{r}=$ 0.673).

\subsection{Scanning electron microscopy.}

SEM images of native and modified SRl starches are shown in Figure 4(a).

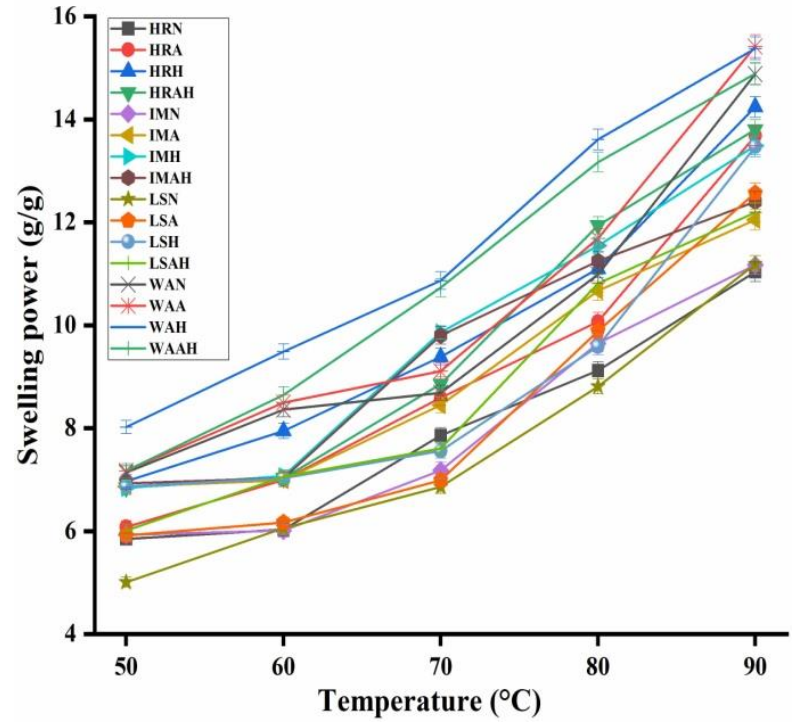

a

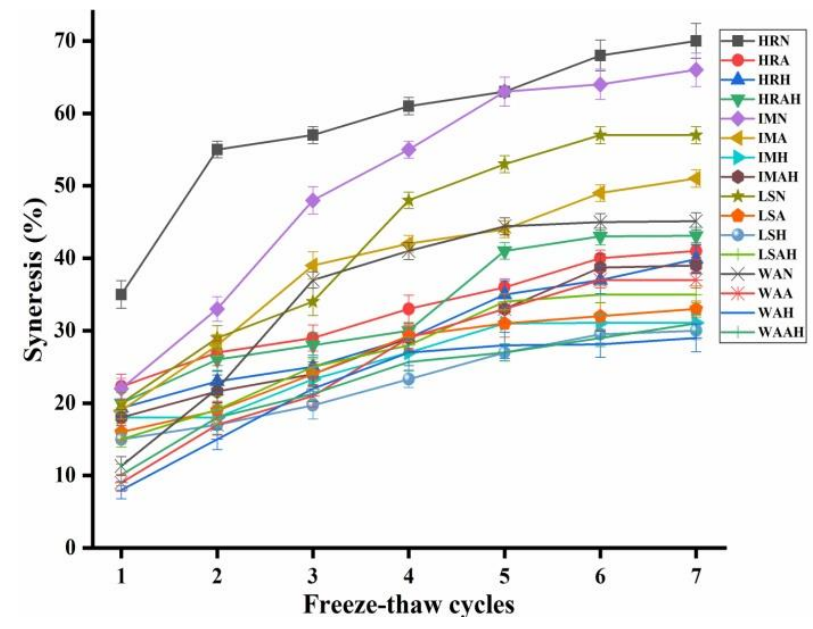

$\mathrm{C}$

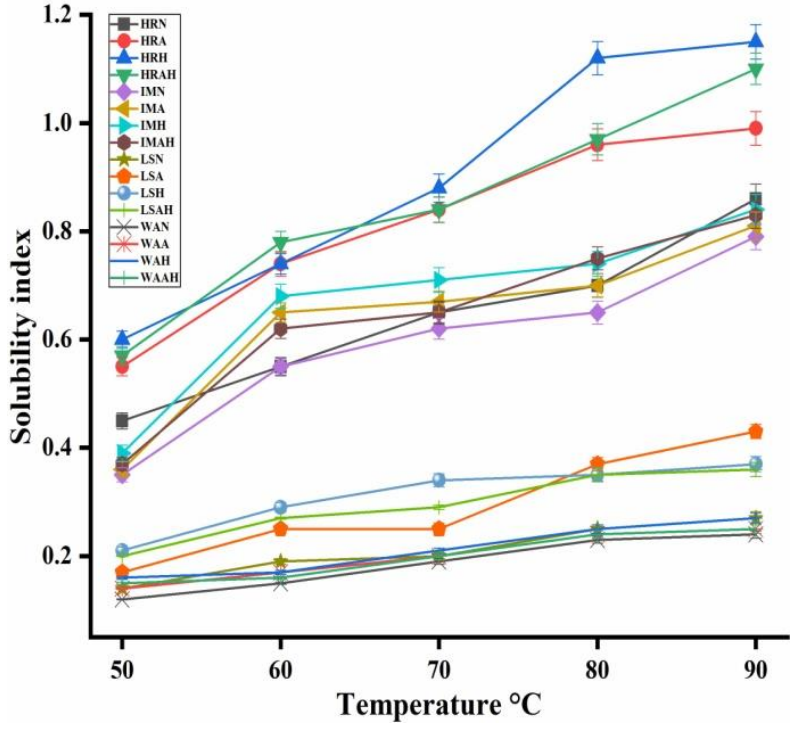

b

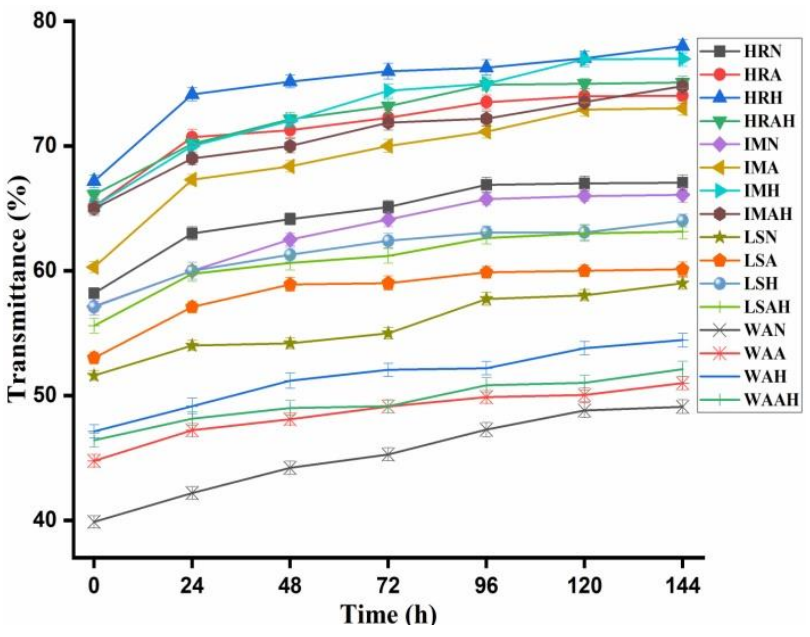

d

Figure 3. (a) Swelling powers, (b) Solubility indices at different temperatures; (c) Freeze-thaw stability; (d) Paste transmittance of native and modified rice starch samples. 
Sizes of native starch granules ranged from 2.3-5.2 $\mu \mathrm{m}$, and granules were polygonal in shape. Acetylation caused minor swelling and agglomeration of granules [36]. However, no wrinkling of the surface was evidenced [39]. This shape change was very limited in dual-modified samples and absent in hydroxypropylated, confirming structural rigidity induced by hydroxypropylation.

\subsection{X-ray diffraction.}

XRD curves are plotted in Figure 4(b). Each sample showed diffraction peaks at $2 \theta$ values of $15.14^{\circ}$ (strong), $17.23^{\circ}$ (peaklet, strong), $18.09^{\circ}$ (peaklet, strong), 23.16 ${ }^{\circ}$ (strong), 26.30 (weak), $30.32^{\circ}$ (weak), and $33.30^{\circ}$ (weak) indicating no effect of modification on A-type diffraction patterns of the native starches. A feeble peak at $20.02^{\circ}$ indicated the presence of a starch-lipid complex. As per Shen et al. (2019), such complexes can hinder acetyl substitution [41]. However, variable drop in crystallinity (\%) values were seen (Table 1). This indicated that substitution caused partial dissociation of crystalline superhelical arrangements other than changes in the amorphous domains' bonding patterns. This notable structural change in the macromolecular arrangement could possibly be caused by steric effects of the introduced groups, which prevented intermolecular hydrogen bonding between glycosidic fractions, reducing chain mobility and partial decoiling of ordered starch helices [42].

\subsection{Thermal properties.}

Thermal transition responses of native and modified starches obtained from DSC are shown in Figure 4(c). The modification resulted in reduced $T_{o}, T_{p}, T_{c}$, and $\Delta H$ of all four starches (Table 1). Acetyl substitution decreased the overall rigidity of starch granules by causing starch chain dissociation, accelerating thermal disruption. Similar changes in acetylated starches have also been reported by other authors $[36,43]$. Higher water penetration into granules after hydroxypropylation caused faster gelatinization indicated by lowered thermal parameter values [16]. Overall, the effect of acetylation on lowering the thermal stability of the starch granules was higher than hydroxypropylation. No typical starch-lipid complex melting peak was observed in DSC. The combined effect of the two modifications resulted in still lower thermal transition values in the dual-modified samples.

\subsection{Pasting properties.}

Lowered thermal stability of the starches also affected their pasting behaviors (Table 2). PVs of all modified starches were higher as compared to native starches, as was also indicated by enhanced swelling powers. Acetylated samples had lower SB, CPV, and PT than the native starches. Low PT could be related to the lower gelatinization temperature, while a low SB indicated only minor retrogradation occurring in the sample pastes. This demonstrated the good stability of the modified rice starch pastes to retrogradation than the native starch pastes [25, 41]. This was also indicated by the lower paste syneresis observed from the freeze-thaw stability test. BD values of acetylated starches were significantly higher than native starches showing greater disintegration and lower tendency for SB. Acetyl groups intruded the amylose-amylose and amyloseamylopectin H-bonds, considerably weakening starch granules. Lower gelatinization 
temperatures, as indicated by lower PT could encourage the acetylated rice starches in low temperature processed foods and benefits industries by lowering process cost. Hydroxypropylated rice starches exhibited decreased BD than native. Significantly lower BD than acetylated samples indicated stronger molecular integrity, as also indicated by relatively higher $\Delta \mathrm{H}$ of the former. Dual modified samples showed lower PT, SB, and increased BD. The increased BD might be attributed to the further weakening of the intra-granular covalent bonds by the higher concentration of substituted moieties.

Table 2. Pasting parameter values obtained from RVA analyses and percentages of rapidly digestible starch (RDS), slowly digestible starch (SDS), and resistant starch (RS) fractions in the raw and modified starch samples.

\begin{tabular}{|c|c|c|c|c|c|c|c|c|c|}
\hline & \multicolumn{6}{|c|}{ Pasting properties } & \multicolumn{3}{|c|}{ Digestibility properties } \\
\hline & PV (cP) & HPV (cP) & BD (cP) & CPV (cP) & SB (cP) & PT $\left({ }^{\circ} \mathbf{C}\right)$ & $\begin{array}{l}\text { RDS } \\
(\%, d b)\end{array}$ & $\begin{array}{l}\text { SDS (\%, } \\
\text { db) }\end{array}$ & $\begin{array}{l}\text { RS (\%, } \\
\text { db) }\end{array}$ \\
\hline $\begin{array}{c}\mathrm{HR} \\
\mathrm{N}\end{array}$ & $\begin{array}{c}3075.00 \pm 24 \\
91 \mathrm{cde}\end{array}$ & $\begin{array}{c}2099.00 \pm 1 \\
7.16 \mathrm{ef}\end{array}$ & $\begin{array}{c}976.00 \pm 2.4 \\
1 \mathrm{a}\end{array}$ & $\begin{array}{c}4499.00 \pm 30 \\
15 \mathrm{~d}\end{array}$ & $\begin{array}{c}2400.00 \pm \\
12.31 \mathrm{e}\end{array}$ & $\begin{array}{c}91.30 \pm 1 \\
.96 \mathrm{j}\end{array}$ & $\begin{array}{c}48.81 \pm 0 . \\
32 \mathrm{j}\end{array}$ & $\begin{array}{c}39.96 \pm 0 . \\
34 \mathrm{gh}\end{array}$ & $\begin{array}{c}11.23 \pm 0 . \\
18 \mathrm{de}\end{array}$ \\
\hline $\begin{array}{c}\mathrm{HR} \\
\mathrm{A}\end{array}$ & $\begin{array}{c}3850.00 \pm 25 \\
17 \mathrm{de}\end{array}$ & $\begin{array}{c}2497.00 \pm 1 \\
8.62 \mathrm{ef}\end{array}$ & $\begin{array}{c}1353.00 \pm 11 \\
.21 \mathrm{ij}\end{array}$ & $\begin{array}{c}4163.00 \pm 29 \\
11 \mathrm{bcd}\end{array}$ & $\begin{array}{c}1666.00 \pm \\
8.79 \mathrm{de}\end{array}$ & $\begin{array}{c}79.10 \pm 1 \\
.49 \mathrm{~b}\end{array}$ & $\begin{array}{c}36.89 \pm 0 . \\
31 \mathrm{j}\end{array}$ & $\begin{array}{c}35.47 \pm 0 . \\
35 \mathrm{hi}\end{array}$ & $\begin{array}{c}27.64 \pm 0 . \\
19 \mathrm{e}\end{array}$ \\
\hline $\begin{array}{c}\mathrm{HR} \\
\mathrm{H}\end{array}$ & $\begin{array}{c}3432.00 \pm 23 \\
17 \mathrm{c}\end{array}$ & $\begin{array}{c}2842.00 \pm 1 \\
4.98 \mathrm{~d}\end{array}$ & $\begin{array}{c}590.00 \pm 4.6 \\
3 \mathrm{~b}\end{array}$ & $\begin{array}{c}4388.00 \pm 28 \\
02 \mathrm{~cd}\end{array}$ & $\begin{array}{c}1546.00 \pm \\
12.64 \mathrm{e}\end{array}$ & $\begin{array}{c}82.40 \pm 1 \\
.68 \mathrm{f}\end{array}$ & $\begin{array}{c}29.83 \pm 0 . \\
22 \mathrm{bc}\end{array}$ & $\begin{array}{c}39.92 \pm 0 . \\
27 \mathrm{~cd}\end{array}$ & $\begin{array}{c}30.25 \pm 0 . \\
13 \mathrm{a}\end{array}$ \\
\hline $\begin{array}{l}\mathrm{HR} \\
\mathrm{AH}\end{array}$ & $\begin{array}{c}3182.00 \pm 24 \\
12 \mathrm{cde}\end{array}$ & $\begin{array}{c}2059.00 \pm 1 \\
2.08 \mathrm{c}\end{array}$ & $\begin{array}{c}1123.00 \pm 10 \\
.99 \mathrm{ij}\end{array}$ & $\begin{array}{c}3718.00 \pm 22 \\
19 \mathrm{abc}\end{array}$ & $\begin{array}{c}1659.00 \pm \\
13.23 \mathrm{e}\end{array}$ & $\begin{array}{c}82.30 \pm 1 \\
.67 \mathrm{f}\end{array}$ & $\begin{array}{c}23.64 \pm 0 . \\
21 \mathrm{ab}\end{array}$ & $\begin{array}{c}44.28 \pm 0 . \\
32 \mathrm{fg}\end{array}$ & $\begin{array}{c}32.08 \pm 0 . \\
15 \mathrm{~b}\end{array}$ \\
\hline IMN & $\begin{array}{c}3069.00 \pm 25 \\
15 \mathrm{de} \\
\end{array}$ & $\begin{array}{c}1458.00 \pm 8 \\
.84 \mathrm{~b} \\
\end{array}$ & $\begin{array}{c}1611.00 \pm 9 \\
01 \mathrm{gh}\end{array}$ & $\begin{array}{c}3108.00 \pm 27 \\
98 \mathrm{abcd}\end{array}$ & $\begin{array}{c}1650.00 \pm \\
8.54 \mathrm{de} \\
\end{array}$ & $\begin{array}{c}83.85 \pm 2 \\
.001 \\
\end{array}$ & $\begin{array}{c}51.47 \pm 0 . \\
24 \mathrm{de} \\
\end{array}$ & $\begin{array}{c}37.66 \pm 0 . \\
25 \mathrm{~b}\end{array}$ & $\begin{array}{c}10.87 \pm 0 . \\
18 \mathrm{de}\end{array}$ \\
\hline IMA & $\begin{array}{c}3157.00 \pm 25 \\
00 \mathrm{cde}\end{array}$ & $\begin{array}{c}1450.00 \pm 8 \\
.76 \mathrm{~b} \\
\end{array}$ & $\begin{array}{c}1707.00 \pm 11 \\
.25 \mathrm{ij} \\
\end{array}$ & $\begin{array}{c}2488.00 \pm 17 \\
70 \mathrm{ab}\end{array}$ & $\begin{array}{c}1038.00 \pm \\
8.94 \mathrm{~d}\end{array}$ & $\begin{array}{c}77.55 \pm 1 \\
.98 \mathrm{k} \\
\end{array}$ & $\begin{array}{c}44.3 \pm 0.2 \\
9 \mathrm{i} \\
\end{array}$ & $\begin{array}{c}35.62 \pm 0 . \\
29 \mathrm{e}\end{array}$ & $\begin{array}{c}20.08 \pm 0 . \\
21 \mathrm{f}\end{array}$ \\
\hline IMH & $\begin{array}{c}3108.00 \pm 21 \\
21 \mathrm{~b}\end{array}$ & $\begin{array}{c}2411.00 \pm 6 \\
.96 \mathrm{a}\end{array}$ & $\begin{array}{c}697.00 \pm 7.8 \\
9 \mathrm{efg}\end{array}$ & $\begin{array}{c}1441.00 \pm 25 \\
05 \mathrm{abcd}\end{array}$ & $\begin{array}{c}970.00 \pm 7 \\
34 \mathrm{cde}\end{array}$ & $\begin{array}{c}77.45 \pm 1 \\
.94 \mathrm{i}\end{array}$ & $\begin{array}{c}34.28 \pm 0 . \\
20 \mathrm{a}\end{array}$ & $\begin{array}{c}41.34 \pm 0 . \\
26 \mathrm{bc}\end{array}$ & $\begin{array}{c}24.38 \pm 0 . \\
22 \mathrm{fg}\end{array}$ \\
\hline $\begin{array}{c}\text { IMA } \\
\text { H }\end{array}$ & $\begin{array}{c}3149.00 \pm 20 \\
05 \mathrm{~b}\end{array}$ & $\begin{array}{c}1464.00 \pm 9 \\
.72 b\end{array}$ & $\begin{array}{c}1685.00 \pm 8 . \\
50 \mathrm{fgh}\end{array}$ & $\begin{array}{c}2432.00 \pm 21 \\
11 \mathrm{abcd}\end{array}$ & $\begin{array}{c}968.00 \pm 7 \\
88 \mathrm{de}\end{array}$ & $\begin{array}{c}75.90 \pm 1 \\
.85 \mathrm{~g}\end{array}$ & $\begin{array}{c}31.39 \pm 0 . \\
28 \mathrm{hi}\end{array}$ & $\begin{array}{c}42.48 \pm 0 . \\
36 \mathrm{i}\end{array}$ & $\begin{array}{c}26.13 \pm 0 . \\
23 \mathrm{~g}\end{array}$ \\
\hline LSN & $\begin{array}{c}3108.00 \pm 24 \\
229 \mathrm{cde}\end{array}$ & $\begin{array}{c}1488.00 \pm 9 \\
.76 \mathrm{~b}\end{array}$ & $\begin{array}{c}1620.00 \pm 6 . \\
92 \mathrm{def}\end{array}$ & $\begin{array}{c}3427.00 \pm 28 \\
22 \mathrm{abcd}\end{array}$ & $\begin{array}{c}1939.00 \pm \\
16.62 \mathrm{f}\end{array}$ & $\begin{array}{c}82.35 \pm 1 \\
.67 \mathrm{f}\end{array}$ & $\begin{array}{c}58.55 \pm 0 . \\
26 f g\end{array}$ & $\begin{array}{c}33.69 \pm 0 . \\
35 \mathrm{hi}\end{array}$ & $\begin{array}{c}7.76 \pm 0.1 \\
9 \mathrm{e}\end{array}$ \\
\hline LSA & $\begin{array}{c}3358.00 \pm 26 \\
00 \text { ef }\end{array}$ & $\begin{array}{c}1608.00 \pm 1 \\
5.00 \mathrm{~d}\end{array}$ & $\begin{array}{c}1750.00 \pm 9 . \\
77 \mathrm{hi}\end{array}$ & $\begin{array}{c}2773.00 \pm 18 \\
06 \mathrm{abc}\end{array}$ & $\begin{array}{c}1165.00 \pm \\
5.87 \mathrm{bc}\end{array}$ & $\begin{array}{c}77.45 \pm 1 \\
.87 \mathrm{~h}\end{array}$ & $\begin{array}{c}52.34 \pm 0 . \\
34 \mathrm{k}\end{array}$ & $\begin{array}{c}33.26 \pm 0 \\
25 b\end{array}$ & $\begin{array}{c}14.4 \pm 0.1 \\
3 \mathrm{a}\end{array}$ \\
\hline LSH & $\begin{array}{c}3214.00 \pm 24 \\
08 \mathrm{~cd}\end{array}$ & $\begin{array}{c}2310.00 \pm 1 \\
9.00 \mathrm{f}\end{array}$ & $\begin{array}{l}904.00 \pm 6.5 \\
4 \mathrm{cde}\end{array}$ & $\begin{array}{c}3967.00 \pm 29 \\
29 \mathrm{~cd}\end{array}$ & $\begin{array}{c}1657.00 \pm \\
6.97 \mathrm{~cd}\end{array}$ & $\begin{array}{c}80.00 \pm 1 \\
.58 \mathrm{e}\end{array}$ & $\begin{array}{c}38.16 \pm 0 . \\
26 \mathrm{fg}\end{array}$ & $\begin{array}{c}43.39 \pm 0 . \\
28 \mathrm{de}\end{array}$ & $\begin{array}{c}18.45 \pm 0 . \\
15 \mathrm{~b}\end{array}$ \\
\hline $\begin{array}{c}\text { LSA } \\
\text { H }\end{array}$ & $\begin{array}{c}3682.00 \pm 27 \\
16 \mathrm{fg}\end{array}$ & $\begin{array}{c}2052.00 \pm 1 \\
8.48 \mathrm{ef}\end{array}$ & $\begin{array}{c}1630.00 \pm 7 \\
33 \mathrm{defg}\end{array}$ & $\begin{array}{c}3427.00 \pm 26 \\
\text { 00bcd }\end{array}$ & $\begin{array}{c}1375.00 \pm \\
8.74 \mathrm{de}\end{array}$ & $\begin{array}{c}76.65 \pm 2 \\
.011\end{array}$ & $\begin{array}{c}32.87 \pm 0 \\
23 \mathrm{~cd}\end{array}$ & $\begin{array}{c}47.75 \pm 0 . \\
21 \mathrm{a}\end{array}$ & $\begin{array}{c}19.38 \pm 0 . \\
16 \mathrm{bc}\end{array}$ \\
\hline $\begin{array}{l}\text { WA } \\
\mathrm{N}\end{array}$ & $\begin{array}{c}3045.00 \pm 17 \\
08 \mathrm{a}\end{array}$ & $\begin{array}{c}1639.00 \pm 1 \\
3.23 \mathrm{c}\end{array}$ & $\begin{array}{c}1406.00 \pm 5 . \\
75 \mathrm{bcd}\end{array}$ & $\begin{array}{c}2619.00 \pm 23 \\
59 \mathrm{abc}\end{array}$ & $\begin{array}{c}980.00 \pm 4 . \\
64 \mathrm{ab}\end{array}$ & $\begin{array}{c}69.55 \pm 1 \\
.54 \mathrm{~d}\end{array}$ & $\begin{array}{c}64.76 \pm 0 . \\
27 \mathrm{gh}\end{array}$ & $\begin{array}{c}39.82 \pm 0 . \\
32 \mathrm{f}\end{array}$ & $\begin{array}{c}4.58 \pm 0.1 \\
7 \mathrm{~cd}\end{array}$ \\
\hline $\begin{array}{c}\text { WA } \\
\text { A }\end{array}$ & $\begin{array}{c}3875.00 \pm 28 \\
14 \mathrm{~g}\end{array}$ & $\begin{array}{c}2129.00 \pm 1 \\
7.01 \mathrm{e}\end{array}$ & $\begin{array}{c}1546.00 \pm 8 . \\
67 \mathrm{fgh}\end{array}$ & $\begin{array}{c}2558.00 \pm 20 \\
17 \mathrm{abc}\end{array}$ & $\begin{array}{c}429.00 \pm 3 . \\
98 \mathrm{a}\end{array}$ & $\begin{array}{c}68.55 \pm 1 \\
.52 \mathrm{c}\end{array}$ & $\begin{array}{c}59.12 \pm 0 . \\
25 \mathrm{ef}\end{array}$ & $\begin{array}{c}49.82 \pm 0 . \\
34 \mathrm{gh}\end{array}$ & $\begin{array}{c}8.94 \pm 0.1 \\
8 \mathrm{de}\end{array}$ \\
\hline $\begin{array}{c}\text { WA } \\
\text { H }\end{array}$ & $\begin{array}{c}3115.00 \pm 20 \\
00 \mathrm{~b}\end{array}$ & $\begin{array}{c}1835.00 \pm 1 \\
2.44 \mathrm{c}\end{array}$ & $\begin{array}{c}1280.00 \pm 4 . \\
98 \mathrm{bc}\end{array}$ & $\begin{array}{c}2258.00 \pm 24 \\
17 \mathrm{abc}\end{array}$ & $\begin{array}{c}423.00 \pm 3 . \\
99 \mathrm{a}\end{array}$ & $\begin{array}{c}68.60 \pm 1 \\
.50 \mathrm{~b}\end{array}$ & $\begin{array}{c}37.77 \pm 0 . \\
22 \mathrm{bc}\end{array}$ & $\begin{array}{c}54.49 \pm 0 . \\
35 \mathrm{hi}\end{array}$ & $\begin{array}{c}7.74 \pm 0.1 \\
9 \mathrm{e}\end{array}$ \\
\hline $\begin{array}{l}\text { WA } \\
\text { AH }\end{array}$ & $\begin{array}{c}3304.00 \pm 23 \\
13 \mathrm{c}\end{array}$ & $\begin{array}{c}1933.00 \pm 1 \\
8.00 \mathrm{ef}\end{array}$ & $\begin{array}{c}1371.00 \pm 12 \\
.20 \mathrm{j}\end{array}$ & $\begin{array}{c}2371.00 \pm 16 \\
78 \mathrm{a}\end{array}$ & $\begin{array}{c}438.00 \pm 4 . \\
06 \mathrm{a}\end{array}$ & $\begin{array}{c}67.75 \pm 1 \\
.47 \mathrm{a}\end{array}$ & $\begin{array}{c}29.53 \pm 0 . \\
21 \mathrm{ab}\end{array}$ & $\begin{array}{c}59.17 \pm 0 . \\
29 \mathrm{e}\end{array}$ & $\begin{array}{c}11.3 \pm 0.1 \\
7 \mathrm{~cd}\end{array}$ \\
\hline
\end{tabular}

\subsection{Infrared spectroscopy.}

FTIR spectra of the samples are presented in Figure 4(d). IR band at $1337 \mathrm{~cm}^{-1}$ exhibited $\mathrm{C}-\mathrm{H}$ stretching of acetyl groups, and band at $1415 \mathrm{~cm}^{-1}$ has been assigned to bending vibration of $\mathrm{CH}_{2}$ and stretching of C-O-O. The IR band at $1637 \mathrm{~cm}^{-1}$ depicted the bending vibration of $\mathrm{H}-\mathrm{O}-\mathrm{H}$. Confirmation of acetyl group binding could be obtained from the intensification of peaks at IR bands range $1540-1850 \mathrm{~cm}^{-1}$, especially at $1642 \mathrm{~cm}^{-1}$ depicting acetyl C-O stretching [44]. The band at $2927 \mathrm{~cm}^{-1}$ was due to symmetrical stretching of $\mathrm{H}-\mathrm{C}-\mathrm{H}$ [45] IR band at $2974 \mathrm{~cm}^{-1}$ was attributed to symmetric and asymmetric stretching of the methyl group formed by https://biointerfaceresearch.com/ 
hydroxypropylation [4]. The intensity of the extremely broadband at $3289 \mathrm{~cm}^{-1}$ ascribed to O-H stretching decreased upon acetylation and increased upon hydroxypropylation and dual modification.

\subsection{Digestibility studies.}

RDS represents the most readily digestible fraction of starch. It is desirable in the diets of people requiring a rapid supply of glucose.
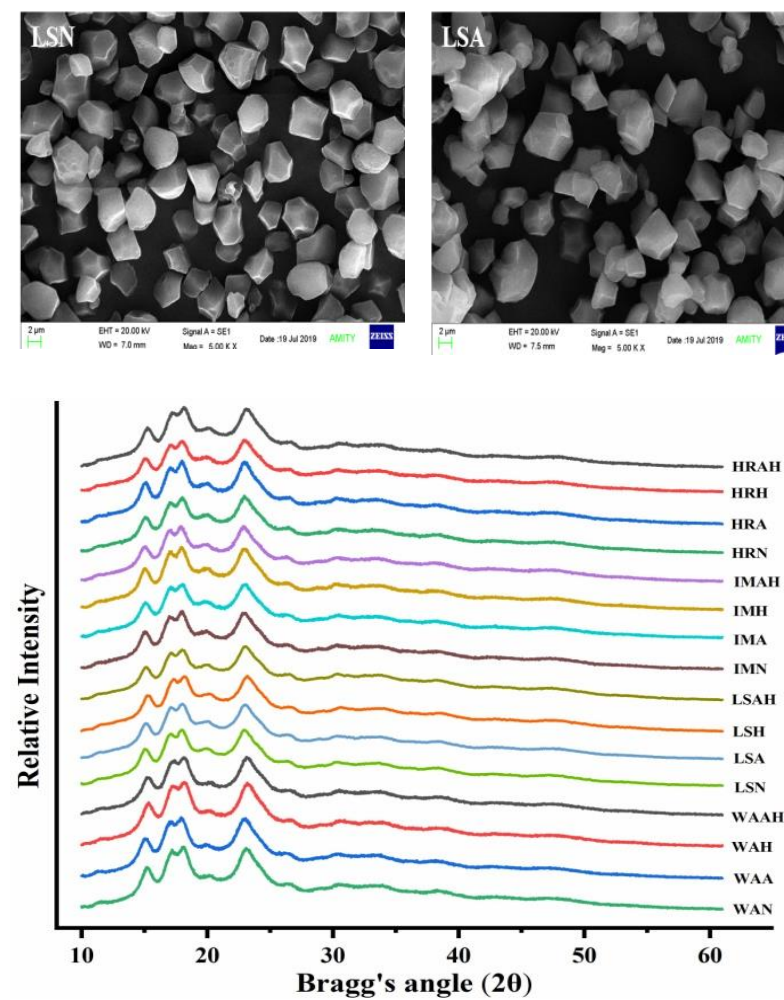

b

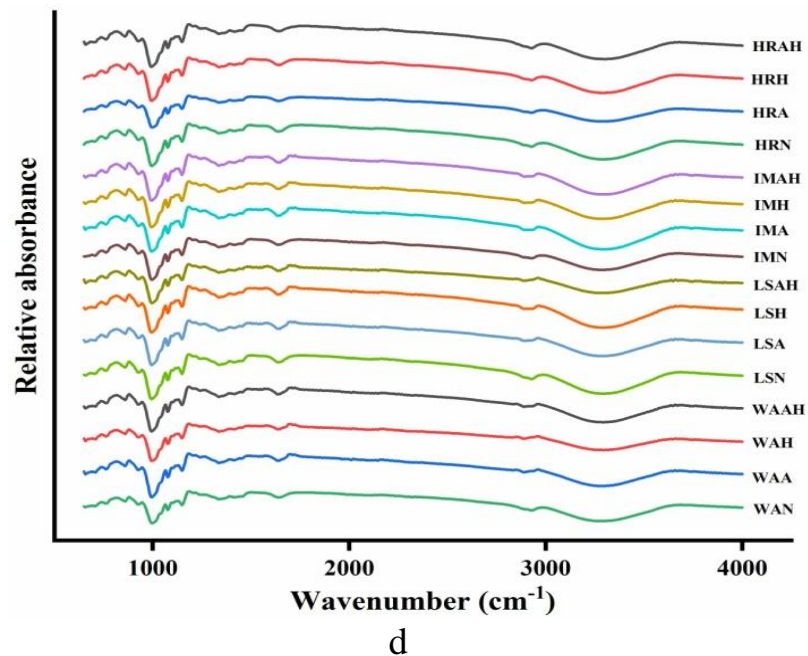

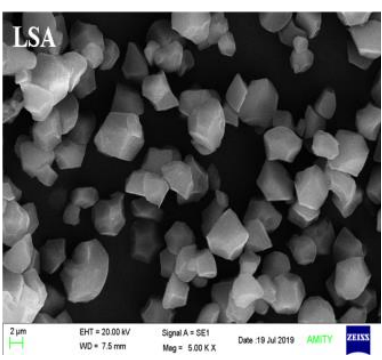

a
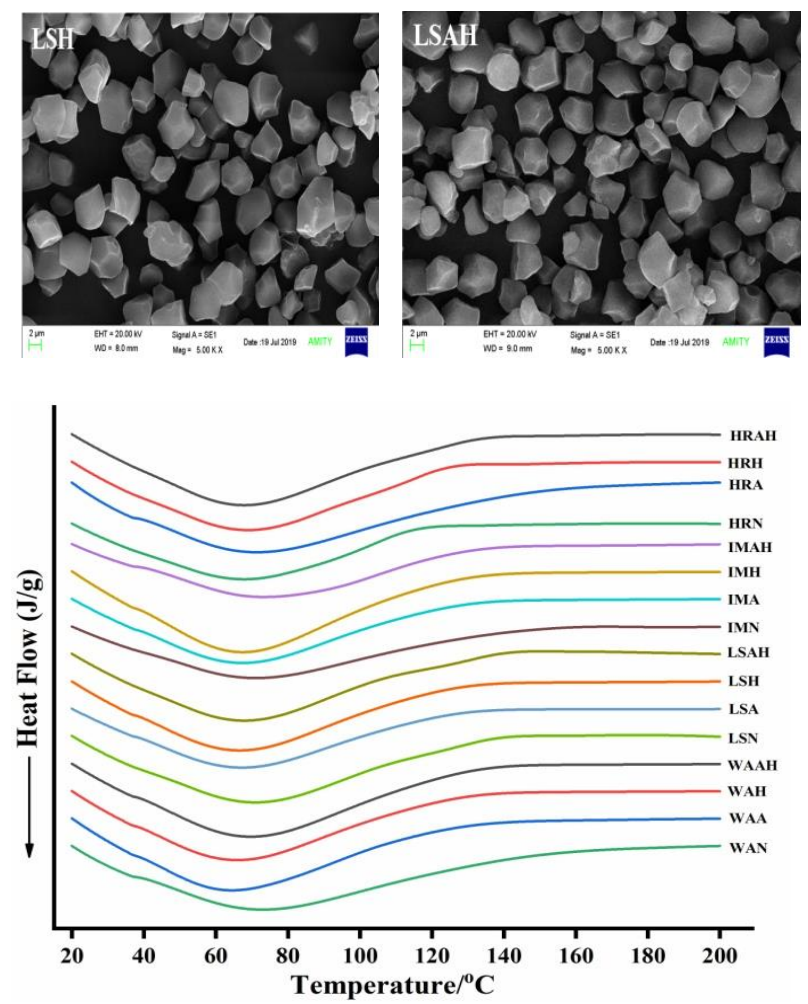

C

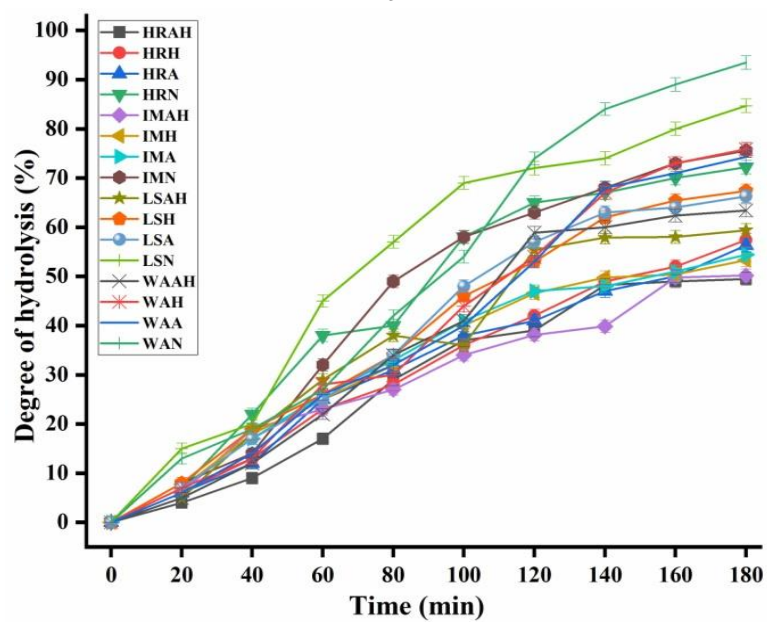

e

Figure 4. (a) SEM images of native and modified SRI starch samples; (b) XRD; (c) DSC; (d) FTIR absorption; (e) Enzymatic hydrolysis patterns of native and modified starch samples.

SDS and RS fractions represent low glycemic and enzyme resistant portions, respectively, as desirable in food formulations for people with diabetes. Values of RDS, SDS, and RS in the 
native and modified starch samples are presented in Table 2. Both acetylation and hydroxypropylation significantly increased RS content in the starches, indicating lower accessibility of the digestive enzymes to the modified matrices. The effect was more prominent HRA, HRH, IMA, and IMH samples. Modified waxy and low amylose starches showed higher rise in SDS than RS. Other than WAH, all hydroxypropylated starches showed higher RS content than acetylated samples. Hydrolysis patterns are plotted in Figure 4(e). Native starches showed distinct three-phase hydrolysis. Acetylated and hydroxypropylated samples of each starch exhibited almost equal degrees of hydrolysis at each interval. A lagging mid-phase elevation followed by an almost stagnant phase at the end for these samples suggested the presence of even more slowly digestible fractions. Dual modified samples had the highest RS content of all the samples and showed longer end phases of hydrolysis. Although modifications caused increased water uptake and faster gelatinization, changes in matrix chemistry were not favorable for the starch digesting enzymes. The modified starches can be used in food formulations with slow glucose release properties.

\section{Conclusions}

Food-grade acetylated, hydroxypropylated, and dual acetylated-hydroxypropylated rice starches were obtained under the reaction conditions (Figures 1,2). The amylose content of the starches primarily decided the extent of modification. Besides general substitution in the amorphous chains, a drop in crystallinity was suggestive of dissociating amylopectin superhelices. Molecular disintegration and enhanced hydrophilicity caused increased SP and SI of the starch granules resulting in lower temperature and extent of gelatinization. Gelatinized modified starches were reluctant to retrogradation and exhibited limited syneresis over freezing and thawing. These could be useful in preventing staling of bakery products that often also encounter temperature fluctuations. The pastes were significantly clearer than native starch pastes. Modified starches showed delayed enzymatic hydrolysis, increased enzyme-resistant SDS and RS fractions, suggesting their remarkably low glucose release tendency.

\section{Funding}

This research received no external funding.

\section{Acknowledgments}

This research has no ackowledgment.

\section{Conflicts of interest}

\section{The authors declare no conflict of interest.}

\section{References}

1. Wang, S.; Chao, C.; Cai, J.; Niu, B.; Copeland, L.; Wang, S. Starch-lipid and starch-lipid-protein complexes: A comprehensive review. Compr. Rev. Food Sci. Food Saf. 2020, 19, 1056-1079, https://doi.org/10.1111/15414337.12550 . 
2. Wang, S.; Xu, H.; Luan, H. Multiscale Structures of Starch Granules. In Starch Structure, Functionality and Application in Foods, Springer Singapore 2020, 41-55, https://doi.org/10.1007/978-981-15-0622-2_4.

3. Hazarika, B.J.; Sit, N. Effect of dual modification with hydroxypropylation and cross-linking on physicochemical properties of taro starch. Carbohydr. Polym. 2016, 140, 269-278, https://doi.org/10.1016/j.carbpol.2015.12.055.

4. Granza, A.G.; Travalini, A.P.; Farias, F.O.; Colman, T.A.D.; Schnitzler, E.; Demiate, I.M. Effects of acetylation and acetylation-hydroxypropylation (dual-modification) on the properties of starch from Carioca bean (Phaseolus vulgaris L.). J. Therm. Anal. Calorim. 2015, 119, 769-777, https://doi.org/10.1007/s10973-014-4092-9.

5. Han, Z.; Shi, R.; Sun, D.-W. Effects of novel physical processing techniques on the multi-structures of starch. Trends Food Sci. Technol. 2020, 97, 126-135, https://doi.org/10.1016/j.tifs.2020.01.006.

6. La Fuente Arias, C.I.; Kubo, M.T.K.-N.; Tadini, C.C.; Augusto, P.E.D. Bio-based multilayer films: A review of the principal methods of production and challenges. Crit. Rev. Food Sci. Nutr. 2021, 1-17, https://doi.org/10.1080/10408398.2021.1973955.

7. Iftikhar, S.A.; Dutta, H. Status of polymorphism, physicochemical properties and in vitro digestibility of dual retrogradation-annealing modified rice starches. Int. J. Biol. Macromol. 2019, 132, 330-339, https://doi.org/10.1016/j.ijbiomac.2019.03.206.

8. Wang, R.; Li, M.; Liu, J.; Wang, F.; Wang, J.; Zhou, Z. Dual modification manipulates rice starch characteristics following debranching and propionate esterification. Food Hydrocoll. 2021, 119, 106833, https://doi.org/10.1016/j.foodhyd.2021.106833.

9. Ashogbon, A.O. Dual modification of various starches: Synthesis, properties and applications. Food Chem. 2021, 342, 128325, https://doi.org/10.1016/j.foodchem.2020.128325.

10. Jain, S.; Winuprasith, T.; Suphantharika, M. Encapsulation of lycopene in emulsions and hydrogel beads using dual modified rice starch: Characterization, stability analysis and release behaviour during in-vitro digestion. Food Hydrocoll. 2020, 104, 105730, https://doi.org/10.1016/j.foodhyd.2020.105730.

11. Cabrera-Canales, Z.E.; Velazquez, G.; Rodríguez-Marín, M.L.; Méndez-Montealvo, G.; Hernández-Ávila, J.; Morales-Sánchez, E.; Gómez-Aldapa, C.A. Dual modification of achira (Canna indica L) starch and the effect on its physicochemical properties for possible food applications. J. Food Sci. Technol. 2021, 58, 952-961, https://doi.org/10.1007/s13197-020-04609-w.

12. Masina, N.; Choonara, Y.E.; Kumar, P.; du Toit, L.C.; Govender, M.; Indermun, S.; Pillay, V. A review of the chemical modification techniques of starch. Carbohydr. Polym. 2017, 157, 1226-1236, https://doi.org/10.1016/j.carbpol.2016.09.094.

13. Colussi, R.; El Halal, S.L.M.; Pinto, V.Z.; Bartz, J.; Gutkoski, L.C.; da Rosa Zavareze, E.; Dias, A.R.G. Acetylation of rice starch in an aqueous medium for use in food. LWT 2015, 62, 1076-1082, https://doi.org/10.1016/j.lwt.2015.01.053.

14. Omoregie Egharevba, H. Chemical properties of starch and its application in the food industry. In Chemical Properties of Starch, 2020, IntechOpen, London, England, https://www.intechopen.com/chapters/68437.

15. Fu, Z.; Zhang, L.; Ren, M.-H.; BeMiller, J.N. Developments in hydroxypropylation of starch: A review. Starch 2019, 71, 1800167, https://doi.org/10.1002/star.201800167.

16. Yang, L.; Zhou, Y.; Wu, Y.; Meng, X.; Jiang, Y.; Zhang, H.; Wang, H. Preparation and physicochemical properties of three types of modified glutinous rice starches. Carbohydr. Polym. 2016, 137, 305-313, https://doi.org/10.1016/j.carbpol.2015.10.065.

17. Shi, X.; BeMiller, J.N. Effect of sulfate and citrate salts on derivatization of amylose and amylopectin during hydroxypropylation of corn starch. Carbohydr. Polym. 2000, 43, 333-336, https://doi.org/10.1016/S01448617(00)00176-4.

18. Fu, Z.; Luo, S.-J.; Liu, W.; Liu, C.-M.; Zhan, L.-J. Structural changes induced by high speed jet on in vitro digestibility and hydroxypropylation of rice starch. Int. J. Food Sci. Technol. 2016, 51, 1034-1040, https://doi.org/10.1111/ijfs.13046.

19. Kaur, L.; Singh, N.; Singh, J. Factors influencing the properties of hydroxypropylated potato starches.Carbohydr. Polym. 2004, 55, 211-223, https://doi.org/10.1016/j.carbpol.2003.09.011.

20. Zhao, J.; Schols, H.A.; Chen, Z.; Jin, Z.; Buwalda, P.; Gruppen, H. Substituent distribution within cross-linked and hydroxypropylated sweet potato starch and potato starch. Food Chem. 2012, 133, 1333-1340, https://doi.org/10.1016/j.foodchem.2012.02.021. 
21. Pal, J.; Singhal, R.S.; Kulkarni, P.R. A comparative account of conditions of synthesis of hydroxypropyl derivative from corn and amaranth starch. Carbohydr. Polym. 2000, 43, 155-162, https://doi.org/10.1016/S01448617(00)00144-2.

22. Juliano, B.O. The chemical basis of rice grain quality. In Proceedings of the workshop on chemical aspects of rice grain quality 1979, International Rice Research Institute, Las Banos, Laguna, Philippines, 69-90.

23. Colussi, R.; Pinto, V.Z.; El Halal, S.L.M.; Vanier, N.L.; Villanova, F.A.; Marques e Silva, R.; da Rosa Zavareze, E.; Dias, A.R.G. Structural, morphological, and physicochemical properties of acetylated high-, medium-, and low-amylose rice starches. Carbohydr. Polym. 2014, 103, 405-413, https://doi.org/10.1016/j.carbpol.2013.12.070.

24. Lee, S.-J.; Hong, J.Y.; Lee, E.-J.; Chung, H.-J.; Lim, S.-T. Impact of single and dual modifications on physicochemical properties of japonica and indica rice starches. Carbohydr. Polym. 2015, 122, 77-83, https://doi.org/10.1016/j.carbpol.2015.01.009.

25. Moin, A.; Ali, T.M.; Hasnain, A. Characterization and utilization of hydroxypropylated rice starches for improving textural and storage properties of rice puddings. Int. J. Biol. Macromol. 2017, 105, 843-851, https://doi.org/10.1016/j.ijbiomac.2017.07.109.

26. Mehboob, S.; Ali, T.M.; Sheikh, M.; Hasnain, A. Effects of cross linking and/or acetylation on sorghum starch and film characteristics. Int. J. Biol. Macromol. 2020, 155, 786-794, https://doi.org/10.1016/j.ijbiomac.2020.03.144.

27. Olagunju, A.I.; Omoba, O.S.; Enujiugha, V.N.; Wiens, R.A.; Gough, K.M.; Aluko, R.E. Influence of acetylation on physicochemical and morphological characteristics of pigeon pea starch. Food Hydrocoll. 2020, 100, 105424, https://doi.org/10.1016/j.foodhyd.2019.105424.

28. Cuenca, P.; Ferrero, S.; Albani, O. Preparation and characterization of cassava starch acetate with high substitution degree. Food Hydrocoll. 2020, 100, 105430, https://doi.org/10.1016/j.foodhyd.2019.105430.

29. Palavecino, P.M.; Penci, M.C.; Ribotta, P.D. Effect of sustainable chemical modifications on pasting and gel properties of sorghum and cassava starch. Food Bioproc. Tech. 2020, 13, 112-120, https://doi.org/10.1007/s11947-019-02381-0.

30. Wang, W.; Shi, Y.-C. Gelatinization, pasting and retrogradation properties of hydroxypropylated normal wheat, waxy wheat, and waxy maize starches. Food Hydrocoll. 2020, 106, 105910, https://doi.org/10.1016/j.foodhyd.2020.105910.

31. Shen, Y.; Yao, Y.; Wang, Z.; Wu, H. Hydroxypropylation reduces gelatinization temperature of corn starch for textile sizing. Cellulose 2021, 28, 5123-5134, https://doi.org/10.1007/s10570-021-03852-4.

32. Sowbhagya, C.M.; Bhattacharya, K.R. Simplified determination of amylose in milled rice. Starch 1979, 31, 159163, https://doi.org/10.1002/STAR.19790310506.

33. Englyst, H.N.; Kingman, S.M.; Cummings, J.H. Classification and measurement of nutritionally important starch fractions. Eur. J. Clin. Nutr. 1992, 46, S33-50.

34. Goñi, I.; García-Diz, L.; Mañas, E.; Saura-Calixto, F. Analysis of resistant starch: a method for foods and food products. Food Chem. 1996, 56, 445-449, https://doi.org/10.1016/0308-8146(95)00222-7.

35. Lan, H.; Hoover, R.; Jayakody, L.; Liu, Q.; Donner, E.; Baga, M.; Asare, E.K.; Hucl, P.; Chibbar, R.N. Impact of annealing on the molecular structure and physicochemical properties of normal, waxy and high amylose bread wheat starches. Food Chem. 2008, 111, 663-675, https://doi.org/10.1016/j.foodchem.2008.04.055.

36. Ashwar, B.A.; Gani, A.; Shah, A.; Masoodi, F.A. Production of RS4 from rice by acetylation: Physico-chemical, thermal, and structural characterization. Starch 2017, 69, 1600052, https://doi.org/10.1002/star.201600052.

37. Lee, H.-L.; Yoo, B. Dynamic rheological and thermal properties of acetylated sweet potato starch. Starch 2009, 61, 407-413, https://doi.org/10.1002/star.200800109.

38. Afolabi, T.A.; Olu-Owolabi, B.I.; Adebowale, K.O.; Lawal, O.S.; Akintayo, C.O. Functional and tableting properties of acetylated and oxidised finger millet (Eleusine coracana) starch. Starch 2012, 64, 326-337, https://doi.org/10.1002/star.201100151.

39. Shubeena; Wani, I.A.; Gani, A.; Sharma, P.; Wani, T.A.; Masoodi, F.A.; Hamdani, A.; Muzafar, S. Effect of acetylation on the physico-chemical properties of Indian Horse Chestnut (Aesculus indica L.) starch. Starch 2015, 67, 311-318, https://doi.org/10.1002/star.201400156. 
40. Lawal, O.S. Hydroxypropylation of pigeon pea (Cajanus cajan) starch: Preparation, functional characterizations and enzymatic digestibility. LWT 2011, 44, 771-778, https://doi.org/10.1016/j.lwt.2010.05.025.

41. Shen, Y.; Zhang, N.; Xu, Y.; Huang, J.; Yuan, M.; Wu, D.; Shu, X. Physicochemical properties of hydroxypropylated and cross-linked rice starches differential in amylose content. Int. J. Biol. Macromol. 2019, 128, 775-781, https://doi.org/10.1016/j.ijbiomac.2019.01.194.

42. Shah, A.; Masoodi, F.A.; Gani, A.; Ashwar, B.A. Physicochemical, rheological and structural characterization of acetylated oat starches. LWT 2017, 80, 19-26, https://doi.org/10.1016/j.lwt.2017.01.072.

43. Colussi, R.; Pinto, V.Z.; El Halal, S.L.M.; Biduski, B.; Prietto, L.; Castilhos, D.D.; da Rosa Zavareze, E.; Dias, A.R.G. Acetylated rice starches films with different levels of amylose: Mechanical, water vapor barrier, thermal, and biodegradability properties. Food Chem. 2017, 221, 1614-1620, https://doi.org/10.1016/j.foodchem.2016.10.129.

44. Lawal, M.V.; Odeniyi, M.A.; Itiola, O.A. Material and rheological properties of native, acetylated, and pregelatinized forms of corn, cassava, and sweet potato starches. Starch 2015, 67, 964-975, https://doi.org/10.1002/star.201500044.

45. Prachayawarakorn, J.; Hanchana, A. Effect of neem wood sawdust content on properties of biodegradable thermoplastic acetylated cassava starch/neem wood sawdust composites. Starch 2017, 69, 1600113, https://doi.org/10.1002/star.201600113. 